Article

\title{
Interwar Blueprints of Europe: Emotions, Experience and Expectation
}

\author{
Trineke Palm
}

Department of History and Art History, Utrecht University, 3512 BS Utrecht, The Netherlands; E-Mail: t.p.palm@uu.nl

Submitted: 3 April 2018 | Accepted: 21 August 2018 | Published: 28 December 2018

\begin{abstract}
The notion of European integration has been contested from its very start. In the interwar period many ideas were floating around on how to shape European unity. These interwar Blueprints for Europe have to be understood in the context of conflicting and contradictory emotions of enmity and amity. This article looks at the emotive vocabulary of the canonical text of Coudenhove-Kalergi's Pan-Europa. It applies an emotion discourse analysis, using Koselleck's notion of "space of experience" and "horizon of expectation". As such it shows the connection between the understanding and use of time and emotions in discourse-thereby demonstrating the necessity of "reading" the blueprints of European integration as highly normative and moral claims on the design of this European order.
\end{abstract}

\section{Keywords}

discourse; Coudenhove-Kalergi; European integration; emotion; interwar; pan-Europa

\section{Issue}

This article is part of the issue "Interdisciplinary Approaches to Studying Emotions within Politics and International Relations", edited by Alex Prior (University of Leeds, UK) and Yuri van Hoef (Utrecht University, The Netherlands).

(C) 2018 by the author; licensee Cogitatio (Lisbon, Portugal). This article is licensed under a Creative Commons Attribution 4.0 International License (CC BY).

There is but one way to avert that ruin: the economic federation of Europe's continental democracies....This is the only road to salvation, alike for European politics and European industry. (Coudenhove-Kalergi, 1923, p. 70, author's own translation)

\section{Introduction}

Before the European integration project started to institutionalize into the European Coal and Steel Community (ECSC) in 1951, many ideas floated around on how to shape European integration. Already during the interwarperiod and during World War II (WWII) there were several plans that envisioned a united Europe. These interwar years were the "first golden age" of the European ideal among intellectuals (Lacroix \& Nicolaïdis, 2010). Recently, Cattani (2017) combined conceptual history with discourse analysis to examine the meaning of concepts such as "European homeland" and "European nation" in the context of the two intellectual conferences organized by the League of Nations in 1933. Similarly, Ifversen (2002) analyzed the interconnected notions of crisis, civilization and Europe in the interwar era.
This article aims to further expand on this by explicitly focusing on the role of emotional vocabulary in relation to the meaning of key concepts of European unity. To this end, it analyzes a canonical text of the time, with a transnational outreach: Coudenhove-Kalergi's Pan-Europa (1923).

There is ample research on the postwar process of European integration based on a rationalist account of European integration as the outcome of the autonomous calculations of different nation states based on their economic, political or military interests (e.g., Milward, 1992), and ideational accounts focusing on transnational networks, their norms and institutions, that pushed for European integration (e.g., Kaiser, 2007; Lipgens, 1968; Müller, 2004). While Lipgens' (1968) work on the blueprints of national resistance movements has been criticized for its "normative overdrive" (Kaiser, 2007), it shows that there is a wide variety of blueprints of Europe that transcend particular national views. While these networks did not necessarily produce a common political European idea, they provided a forum for collective learning, and fostered mutual understanding and trust (Kaiser, 2004). Moreover, they created normative- 
emotional bonds able to withstand domestic/nationalist pressures (Kaiser, 2007).

Concerning the interwar-period, numerous transnational networks can be identified that did contribute to these normative-emotional bonds, such as the RomanCatholic networks (Secrétariat International des Partis Démocratiques d'Inspiration Chrétienne), ecumenical networks (Life \& Work, Faith \& Order) and business networks (Council of Directors of European Industrial Federations [CDEIF]; Colpach-Group).

However, little is known of the ways in which these substantive ideas for a future European order were connected with specific emotives and emotional beliefs. Hence, building upon the "emotional turn" in international relations (IR), this article develops a framework of analysis that highlights the role of emotives and emotional beliefs that were evoked in these transnational visions of Europe, and that served to create moral and political support for them. In particular, it aims to show how experience and expectation are connected by emotives. As such, the focus on how emotives are used to strengthen the substantive ideas (moral/spiritual, political and economic) gives us new insights on how a future Europe was invoked and made attractive to a wider public/audience.

Moreover, beyond the topic of European integration, this article aims to advance research on emotions in IR. While the literature remained rather theoretical or focused on single emotions to account for decision-making failures (Sasley, 2011; see also Bleiker \& Hutchinson, 2008), the methodology of studying emotions in (the history) of IR gained more attention recently (see Clément \& Sangar, 2018). Building upon Koschut (2018b), I develop an emotion discourse analysis, distinguishing between two types of emotion (enmity and amity), enriched by combining this with Koselleck's (2005) notions of "space of experience" and "horizon of expectation". As such this article engages with the need for more structured, systematic empirical research on emotive vocabulary in European integration history.

The central aim of this article is to examine how particular emotives and emotional beliefs were used to gain support for a specific and salient blueprint of European integration. To what extent and how are the experiences and expectations, as expressed in Coudenhove-Kalergi's Pan-Europa, informed by emotives?

Blueprints are understood here as a set of moral/ spiritual, economic and political ideas about a future European order, that are expressed in a particular emotive vocabulary. The next section discusses the relationship between ideas, emotives and emotional beliefs in general, and emotion discourse analysis in particular. Subsequently, I introduce Coudenhove-Kalergi's Pan-Europa (1923) as a canonical text, and emotional landmark, of interwar writings on European unity. In Sections 4 and $5 \mathrm{I}$ analyze the emotive vocabulary of CoudenhoveKalergi's text, focusing on the "space of experience" he refers to and his outline of Europe's future ("horizon of expectation"). In Section 6, based on secondary literature, I reflect upon the emotionalizing effect, reception and response.

\section{Emotive Turn}

\subsection{Ideas, Emotives and Emotional Beliefs}

The emotional turn in IR builds on research in the history and politics of emotions. Frevert's (2011) work on the history of emotions is well-known, showing that our understanding of emotions has changed over time. Moreover, in The Cultural Politics of Emotion, Ahmed (2014) aims to show how the emotionality of text connects individuals to a collective, which includes some at the expense of others.

Research on emotions in IR consists of both macrotheoretical approaches that develop generalizable propositions about political emotions, and microapproaches that examine specific emotions in specific contexts, often decision-making failures (Hutchison \& Bleiker 2014; see also Sasley, 2011). The "emotional turn" in IR encompasses a wide variety of approaches and concepts, ranging from a focus on individual subjective experiences (emotions) and bodily expressions (affection) to more collective systems of feeling (emotional communities, Rosenwein, 2010; Koschut, 2018a), emotional cultures (Moïsi, 2009), institutionalized emotional norms (emotional regimes, Reddy, 2001; see also Crawford, 2000) and conceptual/abstract expressions (emotional beliefs, Mercer, 2010).

This article does not engage with questions about the biological or cultural basis of emotion, but rather conceives of emotional expressions as a strategy to constrain or enable particular substantive ideas about Europe. As such, it does not refer to emotions, but emotives. Emotives are expressed emotions (i.e., emotional vocabulary) that are instrumental in changing, building, hiding and intensifying emotions that are accepted and recognized in a particular community (see Reddy, 2001, p. 105). Emotions are inadmissibly present in any political discourse, however much this discourse tries to present its language in impartial, objective and rational means. In fact, doing so is in itself an emotional strategy, in the sense that it tries to channel specific "non-emotional" emotions, in order to render its contents more convincing.

Of equal importance in the analysis are emotional beliefs (Mercer, 2010). In contrast to emotives that refer to basic emotions, emotional beliefs are more abstract concepts that integrate emotion and cognition (Mercer, 2010, p. 2). Examples of emotional beliefs, in the context of this article, are nationalism, responsibility, solidarity and reconciliation. Emotion is not an addition to these concepts, but is an essential component for understanding its meaning (Mercer, 2010, p. 7). These conceptualizations of emotives and emotional beliefs point out that, although research on emotions is often focused on the level of the individual, there is also a strong collective 
and political dimension to it: "[Emotions] frame what is and is not possible in politics. They reveal and conceal, enable and disable" (Hutchison \& Bleiker, 2014, p. 508). Moreover, they contribute to identity formation, possibly resulting in an emotional community.

As such, emotions are closely tied to morals in at least two ways. First, emotional regimes prescribe what emotives are "appropriate". As such, morals precede emotions. However, emotions and morals also are in a constitutive relationship. So-called moral emotions entail a certain judgment, condemning others (i.e., contempt, anger and disgust), or praising others (i.e., gratitude, awe, elevation) (Haidt, 2003).

It is the connection between ideas and emotives that serves as a mobilization for action. Without ideas, emotives have not object, and without emotives, ideas fail "to produce a sense of obligation or loyalty necessary for collective action" (Koschut, 2018b, p. 286).

\subsection{Emotion Discourse Analysis}

An emotion discourse analysis looks into the emotion potential and emotionalizing effect of political discourse (Koschut, 2018b) and is concerned not so much with the frequencies of specific emotives, but rather with the prevalence of certain emotional patterns/structures, i.e., a certain combination of emotives and emotional beliefs. These master emotives "structure the social meanings and effects of the discourse and thus set the collective standard of emotional expression" (Koschut, 2018b, p. 294).

This article combines emotion and time in discourse (see also Skonieczny, 2018, p. 70). Concerning emotive vocabulary, I distinguish between emotions associated with amity (i.e., empathy, pride, gratitude, grief, honor, respect, compassion and sympathy) and enmity (i.e., fear, anger, disgust, hatred, jealousy, rage) (Koschut, 2014). Moreover, building upon Koselleck (2005), I distinguish between the "space of experience" and "horizon of expectation" of this emotional vocabulary. No emotive can be crafted and disseminated without the presupposition of an existing, collective reservoir of experiences and expectations to tap into. "Space of experience" refers to references to past experiences and reflections on the state of affairs. "Horizon of expectation" refers to references to a future European order. Both can be combined by a positive, inclusive emotional vocabulary or a more negative, exclusive emotional vocabulary (see Table 1). So, negative backward emotions are anger and hatred, whilst trust is a positive emotion with reference to experience. In contrast, forward looking emotions are fear and hope. An example of an emotive that connects experience with expectation is revenge, i.e., it refers to anger based on the past, with the conviction to make up for that in the future. These emotives are not an exhaustive list, but rather examples to show the connection between emotives and notions of time. Moreover, while analytically distinctive, empirically these emotions may be intertwined. The connection of past and future, of experience and expectation, leads to particular blueprints of Europe.

The emotion discourse analysis proceeds in three steps (Koschut, 2018b). First, the selection of texts (Section 3). Second, the mapping of verbal expressions of emotions (Sections 4 and 5). Third, interpreting and contextualizing its political effects (Section 6).

\section{Pan-Europa as Emotional Landmark}

For the purpose of this article, a canonical text on European unity in the interwar period has been selected: Coudenhove-Kalergi Pan-Europa (1923).

Coudenhove-Kalergi's writings are among the first of blueprints of European unity in the interwar-era. During this "first golden age" of intellectual debate on European unity over 600 articles were published on the topic between 1919 and 1939, with a peak between 1925 and the early 1930s (Chabot, 2005, p. 14). While the interwar period was characterized by intellectual debate on European unity, it was also a period of thriving nationalism. In the same year that Pan-Europa was published, national socialist party leader Hitler called for a "national revolution", in strong emotives: "what motivates us is neither self-conceit or self-interest, but only a burning desire to join the battle in this grave eleventh hour for our German Fatherland" (Frevert, 2015). Moreover, Coudenhove-Kalergi's work has been compared to Rohan's Europa (published in 1924 at the same publisher as Pan-Europa), which proposed a culturally united Europe built on a shared Catholic basis (PrettenthalerZiegerhofer, 2013, pp. 167, 176). With 16,000 copies being sold in 1926 Pan-Europa was a best-seller at its time (Prettenthaler-Ziegerhofer, 2012). Translated in many languages it also had a clear transnational reach and was discussed in transnational settings such as the Pan-European conferences that Coudenhove-Kalergi organized as part of his Pan-European Union. At the first conference, in 1926, 2,000 participants from 24 nations gathered in Vienna. As such, the Pan-European Union "constituted a public space where both the meaning of

Table 1. Coding scheme emotion discourse analysis.

\begin{tabular}{lll}
\hline & Space of Experience & Horizon of Expectation \\
\hline Enmity & Hatred, Anger & Fear \\
& Revenge & Hope \\
\hline Amity & Trust & Hope \\
\hline
\end{tabular}


Europe and the vision of a united Europe were discussed" and "provoked new conceptualisations of Europe as a bearer of common identity" (Orluc, 2002, pp. 25, 43).

Although Coudenhove-Kalergi, born in 1894, did have a Catholic background, he "generally ignored the theology of his time" (Sorrels, 2016, p. 213). His biographer Prettenthaler-Ziegerhofer (2001) classifies Coudenhove-Kalergi as a Christian socialist. As we will see, his work consists of emotives with a strong religious connotation.

Coudenhove-Kalergi's approach is based on a neoaristocracy, i.e., a blend of "forward-looking enthusiasm for technological and industrial progress and a backwardlooking authoritarian elitism" (Sorrels, 2016, p. 137). While Coudenhove-Kalergi opposed Hitler and was unequivocal in his condemnation of Nazi anti-Semitism, he flirted with Mussolini's fascism, emphasizing the need for a "wise mixture of the authoritarian and aristocratic principle with what can be healthy in the democratic principle [conceding] room to justice and the enlightened command of superior personalities" (Evola, 1933/2015, p. 47; see also Coudenhove-Kalergi , 1934, pp. 94-96).

While initially a great admirer of the American President Woodrow Wilson, Coudenhove-Kalergi became strongly disappointed in Woodrow Wilson's League of Nations, which suffered from utopian overstretch and did too little for the European dream of a unified continent: "Wilson's attempt to set up an ecumenical League of Nations has failed" (Coudenhove-Kalergi, 1923, p. 20). Coudenhove-Kalergi eventually abandoned his support for the League of Nations in favor of a United States of Europe, inspired by Fried's Pan-Amerika $(1910)^{1}$. In this, he pitted his plan for Europe squarely against the 'Red International', channeling both conservative, 19th century concert ideas and new, fascist dreams for a rejuvenated European unification. As we will see, he does so by positing negative emotives of revenge and destruction against positive emotives of reconciliation and understanding. The United States of Europe is presented as the 6th Europe, after Hellas, Roman empire, Völkerwanderung, Roman-Catholic Europe, and the era of enlightened absolutism. This way Coudenhove-Kalergi (1923, pp. 31-33) presents Pan-Europa as a continuation of a century old project. This Pan-Europa would consist of 26 states (excluding England and Russia) ${ }^{2}$. After a Pan-European conference, the participating countries would sign an obligatory arbitration and guarantee treaty, eventually leading to a customs union. So, Coudenhove-Kalergi prioritizes political and security integration over economic integration, i.e., a customs union is to be developed only after political treaties and security pacts are agreed upon.

The life and work of this Austrian-Japanese politician and philosopher have been evaluated rather neg- atively in the EU integration history literature; he was ineffective (Horner, 2001), and a marginal political figure (Milward, 1997). His political ideas have been criticized as well: "As a blueprint it was imprecise, naïve and optimistic" (White, 1989). Nevertheless, CoudenhoveKalergi's movement was well-known and contributed to a coalition of idealism and commercial interests that was of importance after WWII (Klemann, 1966). Honorary president of the Pan-Europa Movement and Prime Minister of France, Aristide Briand, proposed a European Federal Union in 1930 at the League of Nations. After the war, with the emergence of many other movements for European integration, Coudenhove-Kalergi's position was less central. However, his work was acknowledged, as he was mentioned by Churchill in his famous speech at the University of Zürich in 1946: "Much work has been done upon this task by the exertions of the Pan-European Union, which owes so much to the famous French patriot and statesman Aristide Briand (Churchill, 1946)." Moreover, he was awarded the first Charlemagne Prize in 1950, acknowledging his efforts for promoting European unity.

Hence, although contested, his writings have been central to the interwar thinking about European unity. As such this text is taken as an "emotional landmark" (Koschut, 2018b). ${ }^{3}$ As a product of its time, Pan-Europa is a telling example of the use of emotive vocabulary in the interwar years. It tells us something about the recognized and accepted emotions among the transnational European elites of that time.

\section{Space of Experience in Pan-Europa}

In this section I will take a closer look at the emotional vocabulary of Coudenhove-Kalergi concerning Europe's past and how he understands this to affect his contemporaries' emotional outlook. First, we identify CoudenhoveKalergi's understanding of emotions in international politics. Second, we will see how Coudenhove-Kalergi connects the key emotives of his time (hate and fear) with (a) an emotional belief in nationalism, and (b) a narrow space of experience.

\subsection{Emotions Trump Interests}

While the role of emotions in inter-state relations is debated (see Bleiker \& Hutchison, 2018), in CoudenhoveKalergi's writings they are omnipresent. He argues that "not only are political relations between states functions of national sympathy and antipathy-but national friendships and enmities are also often functions of political relations" (Coudenhove-Kalergi, 1923, p. 122). Coudenhove-Kalergi even claims that the emotional di-

\footnotetext{
${ }^{1}$ For an extensive discussion of the relationship between Fried's work and that of Coudenhove-Kalergi, see Sorrels (2016).

2 England had transformed into "an oceanic empire" with non-European interests, and Russia distanced itself from the democratic system of Europe by proclaiming Sovietism (Coudenhove-Kalergi, 1923, p. 33).

${ }^{3}$ Other relevant writings of Coudenhove-Kalergi in this period consist of Paneuropa ABC (1931), Kampf um Paneuropa (1925) and Europe Must Unite (1938).
} 
mension of the relations among states (Germany and France in particular) trumps rationality and interests ${ }^{4}$, and that these emotions are artificially created over centuries for political-military purposes (CoudenhoveKalergi, 1923, pp. 121-122)-a typical expression of a lingering 19th century preference for "concert" and great power understanding and deliberation (De Graaf, in press).

\subsection{Hate, Fear and Nationalism}

The defining space of experience, against which Coudenhove-Kalergi writes Pan-Europa is World War I (WWI). Against this backdrop, the master emotives that Coudenhove-Kalergi identifies are: hate (Hass) and fear $(\text { Furcht })^{5}$. These emotives of jealousy, hatred, envy, revenge, and malice ${ }^{6}$ fuel a vicious circle of eternal fight in which Europe tumbles from one crisis to another. Coudenhove-Kalergi connects these emotives of hate and jealousy to nationalism and argues that this toxic combination of national hate and national jealousy results in a descent, from month to month, of the spiritual and material European culture (Coudenhove-Kalergi, 1923 , p. 68). Feelings of hate trump those of solidarity (p. 71).

As such, it is the "national chauvinist", who in propagating a European war shows that blind hate against the enemy is stronger than love of one's own (p. 101), that is Coudenhove-Kalergi's (1923) main antagonist. On Coudenhove-Kalergi 's (1923) list of opponents, they are followed by the communists, militarists and protected industries (p. 162). Russia is seen as merely taking advantage of Europe's internal weakness. Coudenhove-Kalergi (1923) even seemed to resist too much of an American interference in European matters: "neither the West nor the East will save Europe: Russia wants to conquer Europe, America wants to buy it" (p. XI).

\subsection{A Narrow Space of Experience}

Coudenhove-Kalergi (1923) observes that the space of experience expands. Because of technical progress, the world becomes smaller (p. 18). Hence, in terms of the "space" of these emotives, Coudenhove-Kalergi (1923) notes that the effects of these feelings of hate are not restricted to the European continent but contaminate the international atmosphere (p. 23). He refers to Europe as an eternal source of uncertainty and anxiety, with analogy to the tempestuous developments in the Balkans (p. 24). Moreover, taking an outside-in perspective, Coudenhove-Kalergi (1923) portrays an image of Europe as once being "feared", but now "pitied" and derided by the upcoming powers (pp. 17, 27).
This progress in the rest of the world contrasted with Europe's decline (Coudenhove-Kalergi, 1923, p. VIII) is due to the fact that the (technical) abilities to expand the horizon of expectations are not grasped by his contemporaries-they lack the necessary imagination (Phantasie) and are backward-looking, according to Coudenhove-Kalergi (1923, p. 98). Because of a lack of imagination, Coudenhove-Kalergi sees the European politics of his days as yesterday's politics rather than the politics of tomorrow (1923, p. VIII). Instead of focusing on how to prevent a future war, more space in the discussions is given to the last war (1923). This experience of war is a too weak foundation to prevent another one ${ }^{7}$.

So, in Coudenhove-Kalergi 's understanding, the eternal focus on "yesterday" is the main cause of Europe's fragmentation (1923, p. VIII). Hence, he suggests the following tactic: Das Übermorgen gegen das Morgen ausspielen [To Set the Day after Tomorrow Against Tomorrow] (p. 87). In other words, he aims to propose to widen the horizon of expectation and accuses his opponents of limiting that same horizon and only looking back.

\section{Horizon of Expectation in Pan-Europa}

In this section we will look at the use of emotional vocabulary by Coudenhove-Kalergi regarding his proposed future European order. He distinguishes between two options-a third option does not exist (1923, p. 54). The fight between anti-European and pan-European is a fight between "Vergangenheit und Zukunft" (p. 168). Key to this choice for a Europe of the past, or a Europe of the future, is the Franco-German relationship.

\subsection{Anti-Europe: Europe of the Past-Revenge \& Destruction}

The default option is to continue on the road of hate, which would inevitably cause Europe's demise, conquered by the upcoming powers (i.e., the United States and Russia) (1923, pp. 21-22). This default option is based on a vicious circle of French politics of destruction and a German politics of revenge. Unforgiveness on both sides lead to a politics of respectively destruction and revenge (p. 134). These two are closely interlinked, and Coudenhove-Kalergi is very much aware of the strength of revenge politics: it is fueled by every act of violence (p. 131).

\subsection{Pan-Europe: Europe of the Future-Reconciliation \& Understanding}

Against this grim picture, Coudenhove-Kalergi proposes his alternative, almost eschatological, horizon of salva-

\footnotetext{
4 "Never was the hate between Germans and French bigger than it is now. This hatred for each other is stronger than reason, stronger than their common interest" (Coudenhove-Kalergi, 1923, pp. 121-122, author's own translation).

5 "Everywhere there is misery, unrest, discontent, hatred and fear" (Coudenhove-Kalergi, 1923, p. VIII, author's own translation).

6 "These states of the West are disjointed and disorganized, in everlasting conflict with one another, and torn by hatred and jealousy (Coudenhove-Kalergi, 1923, p. 23)"; "controlled by mutual hatred and envy, by revenge and resentment" (Coudenhove-Kalergi, 1923, p. 95).

7 "To base the hope for peace on this foundation is short-sighted and hopeless" (Coudenhove-Kalergi, 1923, p. 104, author's own translation).
} 
tion, or redemption (Rettung), liberation and solidarity: European economic integration, based on a political union (1923, pp. IX, 27, 70). The pan-European horizon that Coudenhove-Kalergi aims to provide would be based on a French politics of reconciliation (Versöhnung) and a German politics of understanding (Verständigung) (pp. 124-128). This almost eschatological and salvific horizon unites the "fallen men" of Europe with their once so greatly ordained destiny; thereby channeling a typical sense of Christian teleology into the political realm. To step towards this horizon, this Christian notion of redemption and reconciliation also entails a break with the past; redemption does not arrive automatically - the way needs to be paved with sacrifices and personal engagement (1923, p. 71).

The notion of sacrifice was a key emotive used as part of the war culture rhetoric (Horne, 2004) that Coudenhove-Kalergi is so strongly opposing. Rather than referring to sacrifice as a way to claim moral compensation and renewing antagonism, Coudenhove-Kalergi uses this vocabulary in combination with the notion of reconciliation.

To pave the way for reconciliation and understanding would require a magnanimous, generous and redemptive act (grossmütiger Akt) of France to "teach Germany to believe in the French will to reconciliation to strike a deadly blow to the politics of revenge" (CoudenhoveKalergi, 1923, p. 131). In particular, Coudenhove-Kalergi thinks of "a voluntary renunciation of the occupation of the Rhine" in exchange for an "inter-European guarantee treaty" (1923). This shows that, in Coudenhove-Kalergi's understanding, pan-Europe provides the necessary conditions for a politics of reconciliation.

The notion of reconciliation is of course closely connected to that of sacrifice (Opfer):

Those who love Europe must not shy away from any sacrifice in order to save their continent from this mortal danger. (Coudenhove-Kalergi, 1923, p. 97, author's own translation)

This quote also underlines the point that while Coudenhove-Kalergi speaks about the relationship between France and Germany at a state-level, he also calls on every individual citizen to assume its responsibility. Neutrality in this question of "life and death" is not possible, running away from a decision is high treason (1923, p. 102). Moreover, it recognizes the feelings of enmity.

To break the resistance against Pan-Europa, Coudenhove-Kalergi looks for an awakening (Erwachen) of a pan-European feeling of solidarity (1923, p. 109). This awakening suggests that solidarity is already there, it only has to be activated. Coudenhove-Kalergi distinguishes between two types of solidarity-a solidarity of love and a solidarity of reason. He primarily refers to the latter, i.e., the awareness that the ruin of the other would bring about one's own ruin, would suffice in first instance (1923, p. 124).

In his opposition of anti-European and Pan-European Coudenhove-Kalergi is careful not to position national identity against a pan-European identity. Rather, he refers to Pan-Europe as Übervaterland (1923, p. 156). In later writings he further expands on this relationship between European and national identity, arguing that "just as love for the mother does not detract love for the father, neither does love for the European Mutterland reduce love for the national Vaterländern" (CoudenhoveKalergi, 1931, p. 17). So, national and European identity are no zero-sum relationship (perhaps: "are not mutually exclusive"). This image of the family has a strong emotional connotation, referring to a given relationshipwhether you like it or not. Against the background of the suffering caused by WWI, the maternal reference to Europe underlines its emotional and pacifist connotation (Cattani, 2017, pp. 677-678) ${ }^{8}$.

\subsection{A Narrowing Horizon of Expectation}

As long as there is a democratic regime in Germany, Coudenhove-Kalergi deems it is not too late for reconciliation. Nevertheless, he is pessimistic about the time that is left (Coudenhove-Kalergi, 1923, p. 131). His book aims to underscore the urgent need of European unity, before the horizon of expectation will narrow again. The United States of Europe is "the only salvation from the chaos of the present-before the collapse of the future" (p. 39).

\section{Emotionalizing Effects, Reception \& Response}

Central to Pan-Europe, and Coudenhove-Kalergi's writings in general, is its rather dichotomous character. Coudenhove-Kalergi integrates a sense of time with particular emotives and emotional beliefs. The antiEuropean option is based on backward-looking emotives of enmity, whereas the pan-European order is referred to in terms of forward-looking emotives of amity (Figure 1).

Coudenhove-Kalergi did recognize the dominance of emotives of enmity among his contemporaries and aimed to expand their horizon of expectation to conceive of a different European order. At his Pan-European Congresses he aimed to practise these notions of reconciliation-a highly Christian infused and morally laden emotive-and solidarity-a more social and secularized one. When the German government discussed whether to officially participate in the 2nd Pan-European Congress in Berlin in 1930, Minister of the Interior Wirth, argued in favour with reference to this notion of reconciliation (Prettenthaler-Ziegerhofer, 2001).

Although Coudenhove-Kalergi strongly connects emotion to mobilize forces for his Pan-European order, his Pan-European movement has not proved able

\footnotetext{
${ }^{8}$ Other interwar intellectuals referring to Europe as maternal at symposia initiated by the League of Nations in 1933 in Paris and Madrid are the French Jesuit Yves de la Briere and writer Georges Duhamel (see Cattani, 2017, pp. 675, 677).
} 




Figure 1. Emotional discourse Pan-Europa.

to change the course of history. As Coudenhove-Kalergi (1943) himself points out in his memoirs, his movement was supported by many individual members of governments, but at a more official level, governments ignored it. Opposition did not only come from nationalist groups, but also from pacifists accusing Coudenhove-Kalergi of advocating a Machiavellian pacifism (PrettenthalerZiegerhofer, 2013, p. 163). Coudenhove-Kalergi (1943) recalls that he had not expected Hitler to take over Germany: "When I came back to Germany in 1924, the Hitler chapter seemed definitely closed". Nevertheless, his fear of another cycle of rage and destruction politics came true.

\section{Conclusion}

While research on the interwar plans for European integration is well developed, much less is known about the emotive vocabulary that is involved in those "blueprints of Europe". To this end, this article analyzed CoudenhoveKalergi's canonical text Pan-Europa.

Central to his experience is WWI and the hate between Germany and France. This hate is combined with a strong inclination to look back. As such it leads to a vicious circle of destruction and revenge. These negative emotives associated with nationalism as emotional belief feed into Coudenhove-Kalergi's plan for an alternative European political order which is centered on the emotional and spiritual belief of reconciliation, sacrifice and solidarity-invoking a moralistic appeal and call to action. Coudenhove-Kalergi uses fear of the past to urge his audience to expand their horizon of expectation, and to mobilize their inner redemptive drive. He aims to expand this horizon of expectation with an almost eschatological plan for European unity, in which these negative emotions would turn into feelings of solidarity. While he acknowledges that a solidarity of love may be a bit too much, he calls for a solidarity of reason-and for great acts of sacrifice to meet these high-pitched stakes.

Using Koselleck's (2005) meta-historical categories of space of experience and horizon of expectation allows one to contextualize this emotive vocabulary. We have seen how Coudenhove-Kalergi aimed to connect the emotive of sacrifice to a politics of reconciliation, rather than destruction and resentment. While CoudenhoveKalergi's Pan-Europa is strong in using moral and religious

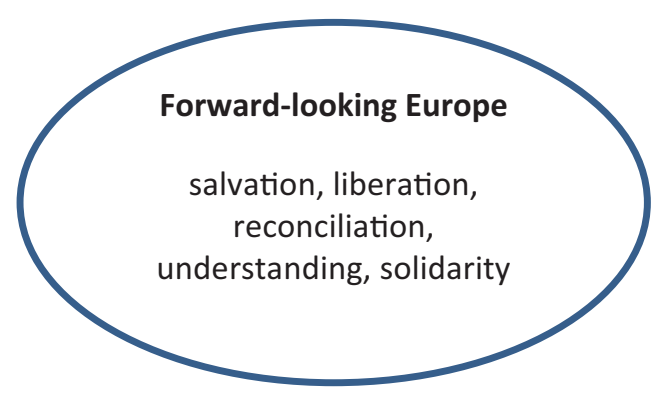

emotives to mobilize his audience, it was not successful in preventing another vicious cycle of French-German politics of hate. As such, this article highlights the constraining force of emotives of enmity on what can be imagined as possible horizons.

This emotion discourse analysis of Pan-Europa has been a limited exercise. There are, at least, three ways to further expand on this analysis. First, compare PanEuropa with Coudenhove-Kalergi's emotional vocabulary after the war. This would allow to reflect upon the relationship between emotives and crisis. Second, compare Pan-Europa with the emotional vocabulary of contemporaries (e.g., Briand's Federal European Union, 1930; Rohan's Europa, 1924). It would allow one to assess to what extent and how Coudenhove-Kalergi's notions of reconciliation and solidarity resonated with contemporary political elites, and to what extent religiously inspired idiom still could find a home in European politics. As Frevert (2015) shows, the Nazi politics of emotions drew also on religious semantics to mobilize its audience. Third, methodologically it would be of interest to investigate in what ways an analysis of the images (i.e., book covers, symbols) confirm the emotion discourse analysis.

\section{Acknowledgments}

This work has been supported by the Netherlands Organization for Scientific Research (NWO) under grant \#36052-190. I would like to thank the members of the research group Blueprints of Hope: Prof. Beatrice de Graaf (PI), Prof. Peter-Ben Smit, Prof. Mathieu Segers, Clemens van den Berg and Jorrit Steehouder. Moreover, the article benefitted from comments from Prof. Eckhart Conze (May 2017) and comments received at EUSA Miami (May 2017).

\section{Conflict of Interests}

The author declares no conflict of interests.

\section{References}

Ahmed, S. (2014). The cultural politics of emotion. Edinburgh: Edinburgh University Press.

Bleiker, R., \& Hutchinson, E. (2008). Fear no more: Emotions and world politics. Review of International Stud- 
ies, 34, 115-135.

Bleiker, R., \& Hutchison, E. (2014). Theorizing emotions in world politics. International Theory, 6(3), 491-514.

Bleiker, R., \& Hutchison, E. (2018). Methods and methodologies for the study of emotions in world politics. In M. Clément \& E. Sangar (Eds.), Researching emotions in international relations. Methodological perspectives on the emotional turn (pp. 325-342). Cham: Palgrave Macmillan.

Briand, A. (1930). Memorandum on the organization of a system of Federal European Union. Paris: Ministry of Foreign Affairs.

Cattani, P. (2017). Europe as a nation? Intellectuals and debate on Europe in the inter-war period. History of European Ideas, 43(6), 674-682.

Chabot, J. (2005). Aux origins intellectuelles de l'Union européenne. L'idee d'Europe unie de 1919 à 1930 [On the intellectual origins of the European Union. The idea of united Europe from 1919 to 1930]. Grenoble: Presses universitaires de Grenoble.

Churchill, W. (1946). Speech delivered at the University of Zurich, 19 September 1946. Council of Europe. Retrieved from http://www.coe.int/T/E/Com/ About_Coe/DiscoursChurchill.asp

Clément, M., \& Sangar, E. (2018). Researching emotions in international relations. Methodological perspectives on the emotional turn. Cham: Palgrave Macmillan.

Coudenhove-Kalergi, R. (1923). Pan-Europa. Wien: Paneuropa Verlag.

Coudenhove-Kalergi, R. (1925). Kampf um Paneuropa. Vienna: Paneuropa Verlag.

Coudenhove-Kalergi, R. (1931). Pan-Europa ABC. Leipzig: Paneuropa Verlag.

Coudenhove-Kalergi, R. (1934). Europa erwacht [Europe awake]! Paris: Paneuropa Verlag.

Coudenhove-Kalergi, R. (1938). Europe must unite. Glarus: Paneuropa edition.

Coudenhove-Kalergi, R. (1943). Crusade for Pan-Europe. New York, NY: G.P. Putnam's Sons.

Crawford, N. C. (2000). The passion of world politics. Propositions on emotion and emotional relationships. International Security, 24(4), 116-156.

De Graaf, B. (in press). Taming the evil passions. Moderation in the international relations. In I. de Haan \& M. M. Lok. The politics of moderation in modern European history. Basingstoke: Palgrave.

Evola, J. (2015). A traditionalist confronts fascism. London: Arktos. (Original work published 1933)

Frevert, U. (2011). Emotions in history. Lost and found. Budapest: CEU Press.

Frevert, U. (2015). Faith, love, hate: The national socialist politics of emotions. In W. Nerdinger \& H.-G. Hockert (Eds.), Munich and national socialism: Catalogue of the Munich documentation centre for the history of national socialism (pp. 479-486). München: Beck.

Fried, A. H. (1910). Pan-Amerika. Berlin: Maritima Verlagsgesellschaft.
Haidt, J. (2003). The moral emotions. In. R. J. Davidson, K. R. Scherer, \& H. H. Goldsmith (Eds.), Handbook of affective sciences (pp. 852-870). Oxford: Oxford University Press.

Horne, J. (2004). The European moment between the world wars (1924-1933). In M. de Keizer \& S. Tates (Eds.), Moderniteit [Modernity] (pp. 223-240). Zutphen: Walburg Pers.

Horner, F. (2001). Parteienkooperaiton der europäischen Christdemokraten. Möglichkeiten \& Grenzen. Ein kommentar [Party cooperation of European Christian democrats. Opportunities and limitations] (pp. 737-752). In M. Gehler, W. Kaiser, \& H. Wohnout (Eds.), Christian democracy in 20th century Europe. Vienna: Bohlau.

Ifversen, J. (2002). The crisis of European civilization. An interwar diagnosis. In M. Mozaffari (Ed.), Globalization and civilization (pp. 151-177). London: Routledge.

Kaiser, W. (2004). Transnational networks of Catholic Politicians in exile. In W. Kaiser \& H. Wohnout (Eds.), Political Catholicism in Europe 1918-1945 (pp. 265-285). London: Routledge.

Kaiser, W. (2007). Christian democracy and the origins of European Union. Cambridge: Cambridge University Press.

Klemann, H. A. M. (1966). Gedanken zur europäischen Integration in den Niederlanden während des interbellums [Thoughts on European integration in the Netherlands during the interwar-era]. In Bosmans, J. (Ed.), Europagedanke, Europabewegung und Europapolitik in den Niederlanden und Deutschland seit dem Ersten Weltkrieg [European idea, European movement and European politics in the Netherlands and Germany since the First World War] (pp. 79-100). Münster: Niederlande-Studien.

Koschut, S. (2014). Emotional security communities. Review of International Studies, 40(3), 533-558.

Koschut, S. (2018a). Appropriately upset? A methodological framework for tracing the emotion norms of the transatlantic security community. Politics and Governance, 6(4), 125-134.

Koschut, S. (2018b). Speaking from the heart: Emotion discourse analysis in international relations. In M. Clément \& E. Sangar (Eds.), Researching emotions in international relations. Methodological perspectives on the emotional turn (pp. 277-302). Cham: Palgrave Macmillan.

Koselleck, R. (2005). Futures past: On the semantics of historical time. New York, NY: Columbia University Press.

Lacroix, J., \& Nicolaïdis, K. (2010). European stories: Intellectual debates on Europe in national contexts. Oxford: Oxford University Press.

Lipgens, W. (1968). Europa-Föderationspläne der Widerstandsbewegungen: 1940-1945; Eine Dokumentation [European Federation Plans of Resistance Movements: 1940-1945; A documentation]. München: 
Oldenbourg.

Mercer, J. (2010). Emotional beliefs. International Organization, 64, 1-31.

Milward, A. (1992). The European rescue of the nation state. London: Routledge.

Milward, A. (1997). The springs of integration. In P. Gowan \& P. Anderson (Eds.), The question of Europe (pp. 5-20). London: Verso

Moïsi, D. (2009). The geopolitics of emotion. New York, NY: Doubleday.

Müller, G. (2004). Anticipated exile of catholic democrats: The secretariat international des partis démocratiques d'inspiration Chrétienne (SIPDIC). In W. Kaiser \& H. Wohnout (Eds.), Political Catholicism in Europe 1918-1945 (pp. 207-217). London: Routledge.

Orluc, K. (2002). A last stronghold against fascism and national socialism? The Pan-European debate over the creation of a European party in 1932. Journal of European Integration History, 8(2), 23-43.

Prettenthaler-Ziegerhofer, A. (2001). Europäische Christdemokraten und die Paneuropa-bewegung von Richard Nikolaus Coudenhove-Kalergi [European Christian democrats and the Pan-Europa movement of Richard Nicholas Coudenhove-Kalergi]. In $\mathrm{M}$. Gehler, W. Kaiser, \& H. Wohnout (Eds.), Christian democracy in 20th century Europe (pp. 574-603). Vienna: Bohlau.

Prettenthaler-Ziegerhofer, A. (2012). Richard Nikolaus Coudenhove-Kalergi, founder of the Pan-European Union and the birth of a new Europe. In M. Hewit- son (Ed.), Europe in crisis: Intellectuals and the European idea 1917-1957 (pp. 89-110). New York, NY: Berghahn Books.

Prettenthaler-Ziegerhofer, A. (2013). Eurotopias: Coudenhove-Kalergi's Pan-Europa and Rohan's Europäischer Kulturbund. In Multiple Europes: Space of crisis. Images and ideas of Europe in the age of crisis: 1914-1945 (pp. 161-177). Brussels: PIE Peter Lang.

Reddy, W. M. (2001). The navigation of feeling: A framework for the history of emotions. Cambridge: Cambridge University Press.

Rohan, K. A. (1924). Europa [Europe]. Leipzig: Der Neue Geist Verlag.

Rosenwein, B. (2010). Problems and methods in the history of emotions. Passions in Context. Retrieved from https://www.passionsincontext.de/index.php/? id $=557$

Sasley, B. E. (2011). Theorizing states' emotions. International Studies Review, 13, 452-476.

Skonieczny, A. (2018) Emotions and political narratives: Populism, Trump and trade. Politics and Governance, 6(4), 62-72.

Sorrels, K. (2016). Cosmopolitan outsiders. Imperial inclusion, national exclusion, and the pan-European Idea, 1900-1930. New York, NY: Palgrave Macmillan.

White, R. (1989). The Europeanism of CoudenhoveKalergi. In P. M. R. Stirk (Ed.), European unity in context. The interwar period (pp. 23-40). London: Pinter Publishers.

\section{About the Author}

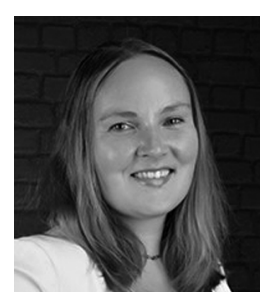

Trineke Palm is a Postdoctoral Researcher at Utrecht University within the project "Blueprints of Hope. Designing post-War Europe: Ideas, Emotions, Networks and Negotiations (1930-1963)". She published in Cambridge Review of International Affairs, Scandinavian Political Studies and Contemporary Politics. 